


Clarke M, Scurry T.

The role of the psychological contract in shaping graduate experiences:

A study of public sector talent management programmes in the UK and

Australia.

International Journal of Human Resource Management (2017)

DOI: https://doi.org/10.1080/09585192.2017.1396545

\title{
Copyright:
}

This is an Accepted Manuscript of an article published by Taylor \& Francis in International Journal of Human Resource Management on 28/10/2017, available online:

https://doi.org/10.1080/09585192.2017.1396545

Date deposited:

$25 / 10 / 2017$

Embargo release date:

28 April 2019

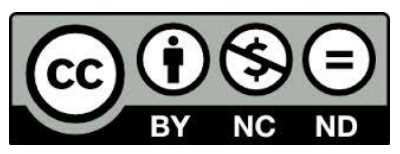

This work is licensed under a

Creative Commons Attribution-NonCommercial-NoDerivatives 4.0 International licence 
The role of the psychological contract in shaping graduate experiences: A study of public sector talent management programmes in the UK and Australia

Dr Marilyn Clarke

University of Adelaide, Business School

10 Pulteney St

Adelaide, AUS 5005

Dr Tracy Scurry (ORCiD 0000-0003-1055-7702)

Newcastle University Business School

Newcastle upon Tyne UK NE1 4SE

We acknowledge the substantial assistance that we have received from Professor Stephen Procter and the anonymous reviewers in developing and shaping this paper. Their comments have been invaluable. 


\begin{abstract}
Although talent management is acknowledged for its role in building competitive advantage, very little research has examined the factors that influence the success of talent management programmes at an individual level. In this paper we explore participant experiences $(n=68)$ from two public sector 'fast track' graduate development programmes, one in the UK and one in Australia. Drawing on psychological contract theory we examine how talent management programmes shape individual expectations and how these expectations influence participant experiences and evaluations of the programme. Our findings highlight the role of both talent management strategy and talent management implementation as well as factors external to the organisation, (such as employer brand and the influence of family and friends), in shaping expectations. Our analysis highlights the impact of multiple agents, particularly line managers, in the ongoing development and fulfilment of the 'graduate psychological contract'. At a practical level, we argue that organisations need to manage expectations by more explicitly communicating what will, or will not, be offered in a graduate fast-track programme. We also suggest that organisations need to consider the importance of line managers in the implementation of talent management.
\end{abstract}

\title{
Keywords
}

talent management, graduates, psychological contract, public sector, fast track, line managers 


\section{The role of the psychological contract in shaping graduate experiences: A study of public sector talent management programmes in the UK and Australia}

\section{Introduction}

In recent years, talent management has become a topic of interest within the business and academic community. Broadly defined, talent management is "the process through which employers anticipate and meet their needs for human capital" (Capelli, 2008, p1) as well as a process for identifying and developing talent for the future. Having the right mix of human resources is recognised as a major source of competitive advantage and a means whereby organisations can meet current and future goals (Collings and Mellahi, 2009) but how this can be achieved has been the focus of considerable discussion and debate. At the macro or strategic level, emotive terms, such as the 'war for talent', have tended to frame and shape debates (Beechler and Woodward 2009) whereas at a more operational level the systems and processes that underpin talent management have largely been overlooked (Collings and Mellahi 2009; Iles, Preece and Chuai, 2010).

The aim of this paper is to contribute to the talent management literature by drawing on psychological contract theory to explore the individual experience of organisational talent management practices. The psychological contract is defined as "the individual beliefs, shaped by the organization, regarding terms of an exchange agreement between individuals and their organization" (Rousseau, 1995, p. 9). Traditionally, psychological contracts have been characterised as either transactional or relational exchanges. Transactional psychological contracts involve economic exchanges within defined time periods (Rousseau, 1990; Conway and Briner, 2005). Distinct from this are relational contracts which are seen to have a long-term focus underpinned by socio-emotional exchanges of non-economic resources and characterised by trust and loyalty (Rousseau, 1990; Cuyper and Witte, 2006). Arguably, this relational perspective underpins talent management programmes that require long-term investments in employees (Festing and Schäfer, 2014) particularly in the case of structured programmes where clear promises are made to participants about the rewards that they can expect to receive in exchange for their contributions (Cappelli and Keller 2014). This is reflected, for example, in organisations that recruit recent graduates to 'entry-level' positions with the aim of creating a talent pool from which to identify and develop future managers. 
Talent management is important for all sectors but the issue is particularly significant for public sector organisations. Globally the public sector is facing unprecedented challenges as it grapples with the pressure of cost cutting and rationalisation, coupled with a steady increase in demand for services (Burke, Allisey \& Noblet , 2013). There are also longstanding concerns over a potential "quiet crisis" if public sector organisations fail to recruit and retain high quality talent as large numbers of the public sector workforce reach retirement age (Lewis and Frank 2002, p395). One strategy to address the knowledge and leadership gaps that will be created by the loss of Baby Boomers is to offer accelerated career progress through what is often referred to as a 'fast track' (Altman 1997) graduate development programme.

Graduate development programmes are well established sources of talent and for many organisations, an important part of their HR strategy (Sturges, Guest, Conway \& Davey, 2002; Collings and Mellahi 2009; Festing and Schäfer 2014; McCracken, Currie and Harrison 2015). Individuals are selected because of their tertiary qualifications and highpotential in keeping with an exclusive approach to talent management (Cappelli and Keller 2014). The critical issue, however, is how this talent should be managed to ensure that potential is realised and that the organisation achieves a positive return on its investment (Hoglund 2012). Evidence suggests that many organisations struggle to manage talent effectively within existing structures (Scullion and Collings 2011; Minbaeva and Collings 2013), a finding that highlights the need to shift the research from a strategic view of talent management to a more operational view that focuses on implementation through appropriate HR practices.

Although there is a growing literature with an organisational level focus (e.g. Connor et al 2008; Farndale, Scullion and Sparrow 2010; Garrow and Hirsh 2008; Poocharoen and Lee 2013), as well as research that examines how employees react to being identified as talent (Bjorkman, Ehrnrooth, Makela, Smale and Sumelius 2013; Gelens, Hofmans, Dries and Pepermans 2014), apart from some useful exceptions (e.g. Bjorkman et al. 2013; Dries and Pepermans 2007) much less research has considered talent management from an employee experience perspective. Given the acknowledged importance of effective implementation for the success of HR practices (Khilji and Wang 2006), and in relation to career management practices specifically (Crawshaw and Game, 2015), we argue that there is a need to further 
understand how individuals experience talent management practices as they are implemented and how this experience subsequently influences outcomes at the individual level.

In this paper, we examine how participants in two public sector graduate development programmes, one in the UK and the other in Australia, experience and evaluate the talent management process. In doing so, we respond to calls for micro-level studies that explore the preferences and expectations of talented individuals (Huang and Tansley 2012; Dries 2013; Tansley and Tietze 2013; Thunnissen et al. 2013; Gelens et al. 2014) and add insight into ways in which HR practices, specifically talent management programmes, shape the employment relationship. The focus of our research is on an under-researched area in the talent management literature (the public sector) and on a distinct employee cohort within that sector (graduate programme participants). Our study adds theoretical insight into talent management by drawing on psychological contract theory to examine how talent management programmes serve to shape and fulfil (or perhaps fail to fulfil) individual expectations, and how this then shapes and modifies participant evaluations of the programme.

Our paper makes three contributions. The first contribution is to provide insight into how talent management strategy (the strategic design and structure of the talent programme) and talent management implementation (practices such as training, development and organisational support) shape the expectations and experiences of programme participants. We highlight how talent management implementation shapes whether programme participants believe that there is congruence between expectations (perceived organisational promises) and actual experiences. Our second contribution is to demonstrate how individual expectations of talent management programmes are shaped prior to joining the programme, and by factors external to the organisation, including the public-sector brand and the influence of family, friends and career counsellors. The third contribution is to demonstrate the impact of multiple agents in the ongoing development and fulfilment of expectations in a shared 'graduate psychological contract'.

The paper begins with a brief overview of the literature on graduate development programmes. We then consider graduate development programmes in relation to talent management from a psychological contract perspective. We present the findings from two public sector case studies to examine talent management as it is experienced at the individual level. We conclude the paper by summarising implications for theory and practice. 


\section{Graduate Programmes as Talent Management}

Talent management is often associated with the creation of talent pools (Kesler 2002; Boudreau and Ramstad 2005a), or the development of "groups of people deemed to have high potential that are seen as a valuable resource for future senior leadership roles" (Yarnall 2011, p511). In creating talent pools, organisations generally choose between two strategies; they may either segment their existing workforce - through practices such as mentoring and succession planning (Boudreau and Ramstad 2005b) - or, they may add to their workforce by recruiting high potentials who demonstrate desirable behaviours, knowledge, skills and competencies (Tansley 2011). Graduate development programmes, the focus of our research, are an example of the second approach which is used to systematically attract, identify, develop, retain and deploy high potential individuals with the capacity to make a significant contribution to the achievement of organisational outcomes (CIPD, 2014; Tansley, 2011; McCracken, et al., 2015).

Fast track graduate programmes have been widely used in the private sector for many years, for example among large accounting firms where top graduates are recruited with the expectation that they have the potential to become future partners (Tansley et al. 2007). Similarly, the public sector has a strong history of recruiting graduates (Taylor 2005; Poocharoen and Lee 2013) as seen in the UK Civil Service Fast Stream programme which emerged in the early 1970s (Pilkington 1999) and more recently in the United States under the Obama administration (Devine and Powell 2008; White House Press Office 2010).

Graduate development programmes, reflect both a 'make and buy' approach (Youndt et al. 2004). That is, graduates are selected for their readymade skills acquired through tertiary study as well as their potential to be developed for key positions in the organisation (Viney et al. 1996; Sturges and Guest 2001; McCracken et al., 2015). Across both sectors, graduate programmes are characterised by job rotations, special assignments, mentoring and skills training (Kuznia 2004) as a cost effective way to develop future leaders and generate organisational commitment (Larsen, 1996).

\section{Graduate programmes and the psychological contract}

When recruited to a graduate development programme individuals begin to form a mental model (a psychological contract) of what can be expected from the employment relationship 
in exchange for talent contributions (Rousseau 2001). Among graduates this mental model is associated with 'graduate identity' as well as the talent management process. To attract top performers, organisations either implicitly or explicitly promise developmental opportunities and accelerated career progression (Festing and Schäfer, 2014) which sends a signal to recruits that they are 'special' and 'different' in line with the overall philosophy of talent management (Huang and Tansley 2012). This affirms their sense of graduate identity (Holmes 2001) and establishes the basis for an emerging psychological contract.

Psychological contracts are important for organisations because they are antecedents to employee outcomes such as satisfaction, commitment, performance, and turnover intentions (Coyle-Shapiro and Kessler 2000). In the case of graduate development programmes it can be argued that the psychological contract reinforces graduates' expectations regarding what they could, and should, receive from the organisation. That is, graduates enter these programmes with the expectation that they will be assigned tasks that allow them to perform at a graduate level thereby enabling them to demonstrate their abilities and to deliver the results expected by employers (Hinchliffe and Jolly 2011). They also anticipate graduate level career management and career progression (Pitcher and Purcell 1998; Sturges et al. 2002; King 2003; Collings and Mellahi 2009).

Festing and Schäfer (2014) propose that an organisation's approach to talent management will influence both the type of psychological contract that develops (relational or transactional) and the extent to which that contract is fulfilled. For career minded graduates, talent management processes have the potential to result in either confirmation or breach of their psychological contract expectations (Arnold and Mackenzie Davey 1999; Sturges and Guest 2001). Where individual expectations are met, or at least partially met, then it is anticipated that over time a positive psychological contract will develop through "a continuous tournament, in which employees are motivated and compelled to develop the qualities desired by the organisation" (Hoglund 2012, p136). Where those expectations are not met there is a greater likelihood of lower job satisfaction, reduced performance and increased turnover (Mabey et al. 1996).

It is important to acknowledge that the psychological contract is not a static arrangement but a "dynamic process that unfolds gradually from the pre-employment stage onwards and 
throughout the different stages of employment" (De Vos et al. 2009, p289). While it would appear that the process of psychological contract formation (commencing with 'pre-joining' expectations) is under-researched and theoretically under-developed (De Vos et al. 2003), there is some evidence that new employees alter their perceptions as they move from the anticipatory stage to the socialisation stage, and as the reality of their employment situation begins to take shape (Robinson et al. 1994). Recent work (Laulié and Tekleab 2016) calls for further research to explore how organisational practices such as recruitment, selection, socialisation and training, shape not only the expectations that are formed, but also evaluations of the fulfilment of expectations at both the individual and group level. We argue that there is also a need for further research on organisational practices associated with talent management. The psychological contract (Rousseau, 1995) is acknowledged as an appropriate frame for analysing talent management (Hoglund 2012; Al Ariss et al. 2014) although to date there has been only limited empirical exploration of the relationship between these concepts. In this article, we use psychological contract theory as a lens to explore the experiences of individuals on two graduate talent management programmes through the following research questions:

1. How does participation in a talent management programme shape the psychological contract?

2. How do graduate expectations develop prior to, and during, the recruitment process?

3. How do met or unmet expectations influence how graduates evaluate the talent management experience?

\section{The research context}

The research was conducted from a multiple case study perspective (Yin 2013). The first case was based on a national, well-established, well-known, but loosely structured programme in the UK (UKGrad). The second case study was a new, low-profile, but very structured, state based programme in Australia (AusGrad) (see text box for details). The value of a comparative case study approach is that it assists in the "understanding of phenomena of interest" (Sekaran 2000, p123) and supports a "deeper understanding of processes and outcomes" (Miles and Huberman 1994, p26). By focusing on two very different case organisations the study provided a vehicle for identifying key factors impacting on talent management experiences within varied structures. 


\section{Organisation context}

Case Study One: UK Public Sector Programme

The UK Public Sector Programme (UKGrad) positions itself as a "Talent Management programme for graduates with the potential to become the future leaders". The website claims "Responsibility will come quickly and you'll get a wide range of experience in a very short space of time”. Entry to UKGrad is highly competitive. In 2012 there were over 21,000 for around 634 positions. As a national programme, it operates in all divisions of the organisation across the country. The centralised recruitment process is extensive and rigorous comprising an online application form followed by online testing. Shortlisted candidates attend a one day assessment centre and a 45-minute interview. Whilst most applicants are external to the organisation, internal candidates can also apply. Successful candidates are allocated to a 'home' department. The programme is not fixed in length, nor does it have a specific common structure across divisions.

Case Study Two: Australian Public Sector Programme

The Australian Public Sector Programme, (AusGrad), is situated in a state based public sector department. Compared to UKGrad, the programme is small, relatively new (established in 2009), fixed length and specific to the department. The programme is competitive with an average of 500 applications per year seeking to fill around 25 positions. The AusGrad website states that it is seeks "talented graduates with a range of skills and abilities" to work in a "creative, energetic and skilled environment". Recruitment is managed by the department and, unlike UKGrad, is a simple process. Applicants complete an on-line form; those who are short-listed attend a face-to-face interview. Successful applicants are normally allocated to a work unit within the department for the duration of their twelve-month programme. All graduates undertake structured development activities through the department's in-house training centre. At the end of the programme individuals are not guaranteed a position in the department although most remain in government.

\section{Research design}

We adopted an explicitly interpretive approach with the aim of exploring the subjective, lived experiences of talent management programme participants within a specific organisational and industry sector context (Denzin and Lincoln 2011). This approach was consistent with 
our focus on the development of the psychological contract and individual experiences in talent management programmes.

Data was collected via 68 semi-structured interviews across the two case study organisations (45 UKGrad, 23 AusGrad). Participants from UKGrad were recruited via an email sent to all programme participants in three departments by the programme department managers. Using a snowball sampling approach (Patton 1990), participants then forwarded the email to other programme participants using established mailing lists and personal contacts. As a result, respondents from across a range of schemes and locations were included in the study. Participants from AusGrad were recruited via an email sent by the programme coordinator to graduates from the 2010 to 2012 intakes who were still working in the public sector and therefore readily contactable. Twenty-five people offered to be interviewed but two later withdrew. Interviews lasted, on average, 60 minutes. Given the geographic distribution of the UKGrad programme, 19 of the interviews were conducted by telephone. All interviews were recorded and transcribed verbatim for analysis. Table 1 details the main characteristics of participants.

Insert table 1 here

In the interviews graduates were asked to reflect on their expectations prior to commencement of the programme, how those expectations had formed, and their actual experiences while on the programme. Psychological contracts evolve through organisational socialisation processes and employee experiences (Lee et al 2011) which means that initial expectations may be difficult to recall or may be blurred by the more complete contract that emerges over time. However, whilst there is evidence to suggest that retrospective reports are subject to bias (Reis and Gable 2000), there is value in using reflective processes to understand how individuals make sense of past career experiences (Bujold 2004) and to identify factors that help shape employee perceptions.

The data were analysed using a template where the researcher compiles a list of codes representing themes identified in the data (King 2004). In the first stage of the analysis each researcher read through the transcripts from her own interviews (UKGrad or AusGrad) looking for common words and themes, making manual notations and sorting ideas under 
broad headings. Through ongoing discussions between the researchers, initial findings were explored and debated with the aim of making sense of individual experiences and identifying how those experiences either supported or challenged our preconceived expectations in relation to graduate programmes (Sandberg 2005). A multiple case study approach was particularly useful in this regard as it provided quite different contexts, and therefore different lenses, through which to explore the research questions, as well as a means of testing the validity and reliability of our interpretations.

In the next stage a common set of themes relevant to both case study organisations was used to create a coding framework derived from relevant literature and consistent with the research questions. This phase involved the use of NVivo10 (QSR 2011). Previously identified words and themes were first coded into free nodes and then grouped into more specific categories (tree nodes). Hierarchical coding was used to identify the relationship between themes such as knowledge and expectations of the public sector, knowledge and expectations of the graduate programme, and between prior expectations and actual experiences. Using NVivo also helped facilitate cross case analysis (interviewee data) and cross case study analysis (UKGrad and AusGrad) (Miles and Huberman 1994).

\section{Findings}

In this section, we present the findings from the two cases. These are structured into two main themes based on the research questions - how the psychological contract develops and how graduates evaluate the talent management (graduate programme) experience in relation to met or unmet expectations.

\section{Building expectations}

All recruitment processes involve an exchange of information between the organisation and potential employees (Sutton and Griffin 2004). During this exchange the organisation either explicitly or indirectly sends signals about what it will offer its employees thus creating expectations that begin to form the foundations for a new psychological contract (Rousseau 1990) prior to the commencement of the employment relationship. In this study, graduate expectations were associated primarily with the public sector brand, the recruitment process and the organisations approach to managing graduate talent as an exclusive talent pool within a specific programme. 


\section{The public sector brand}

The public sector brand has traditionally been based on job security and well defined career paths (Lewis and Frank 2002; Poocharoen and Lee 2013). In addition, despite a lack of strong empirical evidence, the brand is generally associated with opportunities to make a difference to society (Wright 2001). For graduates it appeared that the brand remains strong. It incorporates a generic element (this is a strong and reliable sector in which to be employed); a service element (this is a place where I can make a difference); and a graduate programme element (this is a good opportunity to kick-start my career).

UKGrad was familiar to participants from their time at university. It is a well-established brand in the UK graduate labour market and is heavily promoted by university careers services as a 'top graduate scheme'. The majority of participants expected that UKGrad would be challenging:

\section{So, from all the kind of marketing and the branding you get through the} [organisation] you expect on day one to be arriving and going into a really demanding job that is going to really stretch you and you are going to have to work really hard. Not necessarily work really long hours but it is going to challenge you mentally and it is really going to stretch you. (UKGrad21, 2009, Male)

They also anticipated that it would offer some form of structure, that it would provide them with opportunities to work on 'things that matter', and enable them to make contributions to solving societal problems:

So other things that sort of attracted me to [UKGrad] is that I like being on a sort of structured path. I am happiest when I'm working on projects where I know what I'm doing and also that they end [...] And also the wanting to make myself useful to society. Wanting to contribute back to society. (UKGrad11, 2010, Female)

By contrast, as a new and relatively small programme, AusGrad was described as less prestigious than the more established national public sector graduate schemes but still strongly associated with the public sector brand. The majority knew very little about the 
department before applying however they anticipated that due to its size and position in the wider public sector it could offer a broad range of opportunities and job experiences. Although the programme only lasted for 12 months it was seen as a possible entry point to the relative security of a longer-term career and a wide range of potential career options:

I saw that in the public sector you could sort of start at a lower level and work your way up, so I think that's sort of career opportunities and it's that whole philosophy, once you're in, you're in sort of thing, so you can move around and try different things, rather than just one set role. (AusGrad2, 2011, Female)

For both programmes, the attractiveness and perceived status of the brand clearly influenced the decision to apply and underpinned emerging expectations about public sector employment. In addition, the strength of the brand was reinforced by factors external to the organisation such as positive comments from family, peers and careers advisors, particularly those who had experience working in the public sector and who perceived it to be a good place to work in terms of conditions and opportunities.

\section{Recruitment and selection processes}

Building on the public sector brand, the rigorous recruitment and selection processes, (particularly for UKGrad), reinforced the perception that the programmes are highly competitive and prestigious and that only top graduates should apply. In keeping with the underlying principles of talent management (Festing and Schäfer 2014) entry to a graduate development programme was regarded as offering a certain level of status that would set participants apart from non-graduates. That is, graduate recruits could identify with the concept of being both high performers (in their studies) and high potential (as a result of their tertiary education) (Cappelli and Keller 2014; Gallardo-Gallardo et al. 2013). On the basis of their experiences of the recruitment process the graduates anticipated that, in comparison to standard entry routes, selection into the programme would help 'fast track' their careers through additional support and developmental opportunities. As one UKGrad observed:

I wanted to do something in the public sector in the future and I recognised [UKGrad] as the quickest way to get to a point to kind of get up the ladder ... I could have plugged away in the [organisation but not participating in the UKGrad programme] 
and you know after ten years I might have been [Senior grade] whereas in [UKGrad] it is likely that in three or four years I will be [Senior grade]. (UKGrad1, 2011, Male)

A recurring theme among AusGrads was that the recruitment process was somewhat vague, but at the same time there were explicit promises in relation to training and development. This made the possibility of joining a structured programme very appealing to graduates about to enter the workforce for the first time and was a major factor in the decision to apply:

So I think how they advertise the training and you have all this support and mentoring and everything, that was attractive, and it's not part of every job because a lot of jobs you're just expected to know things and just be able to do things. So, having that stepping stone between just finishing Uni and then going into say a proper job, or whatever you want to call it, that was very important. (AusGrad6, 2012, Female)

At this stage of the recruitment process graduate expectations, in relation to what it means to be selected for a graduate position, were still being formed but were influenced primarily by selective entry and explicit promises of developmental support for recruits who were clearly identified as talent.

\section{The psychological contract takes shape}

The dynamic nature of psychological contract (De Vos et al. 2009) was reflected in the way that, having been accepted into the fast-track scheme, participants described expectations of how the actual programme would operate and what they would receive in exchange for their contributions. The majority anticipated that they would be offered career development support, for example mentoring by more senior staff or networking with other graduates. They believed that a position in a graduate programme would smooth the transition from study to work and hoped that a graduate role, within a graduate programme, would provide more structure and career support than a non-graduate position. Such expectations developed as a result of the organisations approach to managing this group of talent - the talent management strategy (creation of an exclusive talent pool to develop graduates). As one UKGrad explained: 
I hadn't really had a job before, it was a good way to get into the jobs market and obviously if it is a graduate scheme they give you a lot of training to go with it so it's not such a shock. (UKGrad 3, 2012, Male).

Although participants agreed that it had not been explicitly stated, a common assumption was that they would have job rotations in order to gain experience in different roles and across different areas to assist in personal development and career progress. It was unclear how this expectation had developed, although some indicated that they had heard that job rotation was standard practice in graduate programmes. For UKGrads the expectation of mobility across different organisational departments was seen as integral to the concept of a 'fast track' career. UKGrad operated on a scale which ran parallel to existing pay scales. One of the main goals for programme participants was to obtain a permanent senior grade post which was seen as a mark of having 'graduated', although they appeared to be unclear about timeframes and the career consequences of failing to achieve this.

For AusGrads the programme was less about fast tracking their careers and more about being given opportunities to gain work experience across a range of areas, to develop skills and knowledge about the sector, and to build their resume before applying for a permanent position:

\footnotetext{
Really it was experience, I wanted something where I would be given a range of opportunities to really add to my $C V$, so that I would be able to apply for things further on, so I wanted to take ... a graduate position that I could take as much from as possible with a whole range of skills that I could learn through that - so, that was the main appeal for me. (AusGrad7, male 2010)
}

Thus, even before joining the programme, it appeared that a psychological contract, based on a mix of explicit and implicit 'promises', was beginning to emerge. Expectations related to this contract then determined how subsequent experiences would be evaluated and the extent to which participants perceived that talent management promises had been met.

\section{Evaluating the graduate programme experience}

Despite significant differences in how the programmes were structured and executed, four key themes were identified in both sets of data in terms of how graduates evaluated their 
experiences and the extent to which the programme met expectations. These themes were opportunities to demonstrate graduate skills and abilities; opportunities for training and/or development; line manager support and; opportunities to enhance their public sector careers.

\section{Opportunities to demonstrate graduate skills}

A pervasive theme throughout the interviews was graduate eagerness to demonstrate their capabilities, to show initiative, and to be given challenges commensurate with their academic standing. Graduate identity is associated with being different from non-graduates (Holmes 2013) and we found that the participants on both programmes exhibited a number of shared beliefs about the 'level' of work that they expected in terms of challenge and potential to make significant contributions. In describing these beliefs they typically made reference to their status as recent graduates. These expectations of 'graduate level' work, whilst formed prior to entering the talent programme, were clearly amplified by the recruitment and selection processes of both programmes that emphasised the identification of top graduate talent through competitive entry systems.

However, participant's accounts highlight how it was the implementation of the talent management programme that affected the opportunities that they had to engage in the level of work that they expected following the recruitment process. A key factor that influenced the extent to which this was achievable was dependent primarily on where they were located and the type of work that was allocated. For some individuals the work itself was perceived to be suitably challenging and therefore met their expectations in terms of content, focus and level:

\footnotetext{
I was really fortunate in my placement because I was put into a team that took graduates seriously, and I had a manager and a supervisor who saw my potential and gave me challenging work. [ ...] I had two major tasks ready for me when I got there, as well as a lot of ad hoc projects along the way. (AusGrad8, 2011, Female)
}

By contrast, others found that when they joined their programme there was no specific role and no definable tasks apart from low level administrative work:

I have been given quite a lot of little jobs and it is not actually that easy for me to manage my time and take on big projects and the kind of thing that would develop me. 
For instance, $[. .$.$] a lot of the time I am booking meetings [...] administrative roles$ are good in a way, it's good to learn those but I have been doing it for so long now that it's actually just getting in the way of doing proper work. Sometimes I feel slightly under-utilised. (UK Grad37, 2010, Male)

An AusGrad mirrored the same concerns:

I think a lot of us found similar experiences in terms of being a graduate officer... people don't really understand what that means, people would give you, yeah quite basic tasks and not really support you to reach further to work at a higher level. (AusGrad10, 2010, Female)

Many were surprised to find they had been placed in a role that did not appear to be a good match for their abilities and degree qualification, and that they were not given a clear rationale for that decision. The perceived lack of suitable, 'graduate-level' work led to frustration that they were being treated as a resource to fill gaps caused by recruitment freezes associated with public sector cost cutting, rather than as graduate talent.

\section{Training and development}

The promise of training and developmental opportunities was an important factor in deciding to apply to a graduate programme and a basic element in the emerging psychological contract. Graduates have ready-made skills and knowledge that can be applied immediately, however, programme participants had developed expectations that they would be offered training and developmental opportunities to further enhance their graduate capabilities and thus evaluated their experiences in light of how well the organisation delivered on this promise.

Many UKGrads made a clear distinction between experiences in their specific role and overall programme experiences and opportunities. Whilst some felt that their role met expectations in terms of day-to-day work, they felt that the overall development, support and fast-tracking that had been 'promised' were not being delivered and as a consequence they felt let down. Across the organisation training and development systems were variable. Whilst the majority reported a positive experience in terms of general orientation at the start of the programme and 
subsequent training for specific roles, many questioned the extent to which opportunities for personal growth and development were made available. In fact, many participants expressed surprise at how much responsibility they had for their own development;

My experience of the [programme] has been its surprisingly unstructured and very much you are left to your own devices....you are given the label of a 'UK Grad' and then it is up to you to try and use it to your own benefit .... I don't feel like a lot of opportunities have been presented to me. It is a lot more what I've looked up for myself and kind of pushed to go on. (UK Grad5, 2010, Male)

Despite a lack of explicit detail about the organisation and structure of the programme during the recruitment process, the majority had expected that they would be deployed as organisation wide resources and thus able to access opportunities across departments. This, however, was not the case. Individuals were allocated to specific departments for the duration of their UK Grad experience. 'Home departments' and roles varied significantly in terms of experiences and developmental opportunities and as a result some had developed strategies to 'relocate' to other departments or to obtain specific roles that would provide better opportunities to develop the necessary competencies to obtain a senior grade. Furthermore, many expressed frustrations that re-structuring and budget cuts meant fewer posts were available to provide the range of 'on the job experience' required for promotion. This led one participant to describe UKGrad as a 'false promise':

What is applied for and stated on the website to recruit you is not what you are given...the deal in inverted commas - there isn't one. Different salaries, different training budgets, different career progression. (UK Grad26, 2005, Male)

AusGrads faced similar experiences. The majority had anticipated that the programme would include either rotation across different units/departments or exposure to the functions of other units so that they could gain wide-ranging experience before applying for a long-term position or promotion. However, in most cases this did not happen and only those with highly supportive managers were able to negotiate short-term placements across two or three areas. Another concern was that, although they were recruited to a year-long developmental programme, within months, or sometimes weeks, of commencing they were pressured to 
begin applying for jobs. This shifted the focus from development to simply finding a position:

The graduate programme for me was not about getting a job; it was about the opportunity for development [...]. But [...] you're told by some people from a very early stage, to apply for jobs, to really be focused about that...it was almost like an obsession, not saying are you enjoying your work, are you finding it fulfilling, is it meeting your career goals? (AusGrad2, 2011, Female).

For AusGrads the most positive aspect of the programme was the amount of training that was offered, particularly as this had not been communicated during the recruitment process. The department had its own training centre which offered structured courses as well as one-off personal development sessions. Through these events participants were introduced to mentors (often graduates from previous intakes) and were encouraged to develop internal networks. This highly structured programme contrasted significantly with some of their day-to-day work experiences. It acted as a counterbalance to the lack of graduate level work that many experienced and conveyed an unexpected degree of support from the organisation. Importantly, it exceeded prior expectations and thus contributed to a more positive psychological contract.

\section{Line manager support}

A third key factor influencing how graduates evaluated the program was level of support from line managers. Direct supervisors are critical to how graduates are deployed and developed and thus have a significant role in determining the effectiveness of talent management programmes (Tomprou and Nilolaou 2011). Across both programmes some graduates had worked with highly supportive managers who allocated suitable work, encouraged them to undertake developmental activities and provided mentoring and career guidance. A number of participants noted that their manager had entered the public sector through a graduate programme and therefore had a good understanding of the career needs and motivation of young graduates: 
I think that's half the battle, having a line manager who knows what UKGrad is and recognising that it's not just about the job you are doing it's about your wider development ambitions as well. (UKGrad3, 2009, Female)

(My manager) was brilliant in guiding me, and she understood the public service, and so, she taught me everything that she sort of knew and was very hands-on in that teaching, but also was quite happy to let me do my work and to give me that opportunity. (AusGrad7, 2010, Male).

On the other hand, others had received low levels of managerial support ranging from apathy to open hostility:

Initially I spoke to my manager, didn't get any response from her, I then went to other members in my team, didn't get much of a response from them. Then went to other teams, didn't get much response from them, and then during a meeting I just got really frustrated, I said, I literally have nothing to do and then this guy stepped up and said 'I'll be the supervisor' and he was great. (AusGrad2, 2011, Female).

To a large extent, participants appeared to be polarised in their views about line managers, either praising them for their concern and support, or expressing frustration at the lack of clear direction that had been provided. Graduates acknowledged that the degree of support was closely linked to managerial workloads which often left little time for dealing with new staff, however, there was clearly a strong expectation that within the graduate programme they would be offered-well defined graduate level tasks and that they would be supported and mentored by their manager.

\section{Career opportunities}

Despite significant and ongoing structural change, career pathways and job security were still positively associated with the public sector brand. Graduates stressed the desirability of pursuing a public sector career, not just the desirability and benefits associated with participating in a graduate programme. Career opportunities thus contributed to formation of the psychological contract and were used to evaluate the extent to which the contract was being met. 
Among UKGrads a common concern was the lack of support for career development and progression. Having joined the programme expecting that this would be the start of a long-term public sector career, many graduates felt that they had been left to plan and manage their career as best they could. Even those who were proactive in career self-management encountered difficulties such as managers who were reluctant to let them move to another role despite the fact that staying might stifle their progress:

It was quite difficult to [move roles], quite a lot of aggravation. In the end everyone accepted it that I would have to move. There is a bit of a catch between sort of the UKGrad side of it and the business side of it. They sort of thought 'yes' but we need someone to do this. And I was 'well, do you need me to do it'? Get someone else to do it was the point I was trying to make. (UKGrad 4, 2009, Male)

Importantly, many participants felt that the organisation had failed to meet its promises and thus had become disappointed by, and disillusioned with, the career opportunities available to them. By contrast, and primarily due to the short-term nature of the programme, AusGrads had very different experiences. The department was quite explicit in stating that at the completion of the programme there were no guarantees of ongoing employment which meant that the focus tended to be on finding a position rather than starting a career. In addition, graduates were aware that future career opportunities were constrained by budget cuts, job cuts and job freezes:

There's a lot of anxiety about jobs, because jobs need to be cut, just because there's not enough money, we need to find savings. So that culture is coming through a bit, which doesn't make sense either because I think they're going to lose very talented people because young people who've got options and they're not going to hang around in this climate for too long I don't think. (AusGrad2, 2010, Female)

Yet, despite these concerns many of the participants, from both programmes, still expected that opportunities should, and would, emerge for talented graduates. They were optimistic that the training and development offered through the programme would lead to varied career paths, either in the department or across the wider public sector, and that having been selected into a graduate role they would progress to higher level roles at an accelerated rate. 


\section{Discussion}

This paper used psychological contract theory to explore talent management programmes in a public sector context. Based on our findings, figure 1 provides a framework to help identify and understand the inputs and processes associated with the development of a talent based graduate psychological contract. It also helps explain how graduates experience and evaluate 'fast track' programmes. .

\section{INSERT FIGURE 1 HERE}

A key finding from this research was the importance of distinguishing between talent management strategy and talent management implementation. We define talent management strategy as the strategic design and structure of talent management programmes, such as the decision to adopt a 'highly engaged' talent management approach that actively invests in the development of individuals (Festing and Shafer, 2014). Talent management strategy helps shape the branding of these graduate-entry programmes and how they are then 'sold' to participants which plays a significant role in the formation and development of individual expectations. Talent management implementation refers to the activities and processes that facilitate the talent management strategy, for example formal training and career development opportunities, organisational support and graduate placements. Talent management implementation is critical in the early experience phase as well as contributing to how the programme is experienced and evaluated over the longer-term.

In both case study organisations talent management strategies were communicated during attraction and recruitment practices prior to the start of the employment relationship. In this phase graduate perceptions and expectations were shaped and reinforced through organisational approaches to managing talent, that is, the creation of an exclusive talent pool to develop graduates, as well as more explicit 'promises' (De Vos et al. 2003; De Vos et al. 2009; De Vos and Dries 2013) made by the organisation which acted as cues in the ongoing formation of a more complete cognitive schema (Lee et al. 2011). Although the organisations used very different recruitment methods, graduates in both programmes perceived that they had been chosen because of their graduate skills and their potential to 'fast-track' through the 
ranks to leadership positions. In keeping with both psychological contract theory (Festing and Schäfer 2014) and social exchange theory (Blau 1964), graduate recruits anticipated that they would be placed in positions where they could make a worthwhile contribution to the organisation and that, in return, the organisation would invest in their development.

In addition to organisational factors (e.g. programme branding, attraction, recruitment and selection processes) pre-programme expectations were also impacted by factors external to the organisation and that predated the employment relationship, such as public sector brand, influence of family and friends and careers counsellors. The combination of organisational and non-organisational factors resulted in participants developing shared expectations, underpinned by a sense of graduate identity (Holmes, 2013), about what the programmes would offer which further served to shape their emerging psychological contract.

Building on existing psychological contract theory (Cullinane and Dundon 2006), we noted that the way in which recruitment was framed, as well as the wider context of public sector employment, resulted in the emergence of multiple psychological contracts which participants then used as lenses to evaluate their experiences. All participants displayed a sense of a shared 'graduate psychological contract', underpinned by notions of graduate identity (Homes, 2013) but how that contract evolved at an individual level was dependent on context and experience. In relation to skill and career opportunities, prior research has shown that graduate career progress is associated with initial roles and tasks, for example graduate level projects that offer "interesting job content and career opportunities" (De Vos et al. 2003, p290). In addition, employer inducements, such as personal support, skill development, training and career opportunities (Lee et al. 2011) help build a positive psychological contract which increases the likelihood that graduate expectations will be met and that graduate performance will be enhanced, thus meeting talent management goals. In this study participants from both programmes recognised and accepted that budgetary constraints within the public sector meant fewer job opportunities and the erosion of clearly defined career paths (Burke et al. 2013) but as members of a talent pool they anticipated privileges not normally available to other employees, such as opportunities to demonstrate existing capabilities and build new skills (Gallardo-Gallardo et al. 2013). When those opportunities did not eventuate they perceived that their psychological contract had not been fulfilled. 
As the findings highlight, although both organisations adopted an exclusive talent management strategy their promises were significantly different. For AusGrads the message conveyed from the initial recruitment phase was that although they would not be offered job security they would be offered training, development and on-the-job experience to support their future career. This message then translated into a more transactional psychological contract through which programme participants evaluated formal training and development opportunities (Rousseau 1990). Over time, some AusGrads began to shift to a more relational contract due to support from the HRM unit and line managers as well as positive career progression, while others, particularly those who received limited line manager support, retained a more transactional approach. By contrast, UKGrads entered the programme on the understanding that they could expect a long-term career punctuated by organisationally supported development and steady, if not accelerated, progression. Within the structures of this more relational contract (Rousseau 1990) many expressed frustration and disappointment. Yet despite apparent incongruence between expectations and outcomes they chose to remain within the public sector. The reasons for this choice were unclear but there were indications that some had sought to deal with the apparent incongruence by adopting a more pragmatic approach reflective of a transactional psychological contract. For example, some graduates had initiated career moves rather than waiting for support and direction from management.

In both organisations there were indications that graduates differentiated between promises at the organisational level (for example the HRM department) and at the unit level, where their development could be either supported or hampered by line manager practices. By doing so, they were able, to some extent, to rationalise the lack of congruence between initial promises and expectations and subsequent experiences (Coyle-Shapiro and Parzefall 2008). We suggest that while recruiters and HR managers are the 'contract makers', line managers tend to be 'contract facilitators' in the talent management process and thus play a key role in whether both explicit and implicit contracts are fulfilled or breached (Tomprou and Nilolaou 2011). Within HRM there is increasing recognition of the critical role played by line managers within HRM (Yarnall 1998, Khilji and Wang, 2006; Jenner 2008), although this has received very little attention in the talent management literature. Yet, to a large extent, line managers determine how HR policies are implemented and enacted (Bowen and Ostroff 
2004). They are described variously as a ‘crucial intermediary' (Purcell and Hutchinson 2007) or the 'connecting thread' (Shipton et al. 2016), with day-to-day behaviour and treatment of employees sending explicit signals of how much the organisation values its human resources (Alfes et al. 2013a; Alfes et al 2013b). Line managers have thus been associated with job satisfaction, commitment and extra-role behaviours (Gilbert, De Winne and Sels 2011; Harney and Jordan 2008). From a social exchange theory perspective (Blau 1964), when employees have positive experiences in relation to HR policies and line manager behaviours, they are more willing to engage in high levels of performance. For their part, organisations anticipate that greater investment in employee development will lead to higher performance levels, commitment and "felt obligations to develop skills and apply these in service of the organization" (Hoglund 2012, p135). Alternatively, when there is a lack of congruence between HR promises (particularly those offered during the recruitment phase) and HR practices, (as experienced in day-to-day activities and in interaction with line managers), then graduate engagement is likely to be impacted.

These findings suggest that although the 'graduate psychological contract' is notionally between the employee and the organisation, in practice it involves multiple agents including the HR department, senior managers and line managers. The way in which these multiple agents manage graduate programme participants determines the extent to which individuals perceive that there is congruence between what was promised and what has been delivered across the various levels in the organisation (Shipton, Sanders, Atkinson and Frenkel 2016).

Line managers clearly play a critical role given that they have primary responsibility for the implementation of talent management in terms of task allocation, day-to-day guidance and career development support. Unless the line management of graduates reflects and supports the overall aim of a talent management programme then the organisation is likely to be sending mixed messages about how much it values its future leaders. At a practical level this may result in a failure to fully develop graduate potential and the possibility that better employees will choose to leave the organisation due to breaches of their psychological contract. On a more positive note, as shown in a recent study, line manager support for developmental HRM, such as offered in talent management programmes, can 'rebalance' the psychological contract, reducing the transactional elements and increasing relational elements (Bal, Kooij and De Jong 2013). 


\section{Conclusion and implications}

The goal of this study was to explore the subjective experience of talent management within a public sector organisation and the role of the psychological contract in shaping graduate experiences. Much of the existing talent management literature is either from a theoretical (Cappelli and Keller 2014; Tarique and Schuler 2010) or an organisational (Ashton and Morton 2005; McDonnell et al. 2010) perspective but by considering the individual experience our findings add to, and expand, both theory and practice in the following ways.

First we have identified the value of the psychological contract for understanding how individuals experience and evaluate talent management programmes. Addressing an acknowledged limitation of existing psychological contract research, we adopted a qualitative approach to move beyond the identification of dimensions of the psychological contract (Conway and Briner, 2005) to an exploration of how both organisational talent management strategy and talent management implementation shape the psychological contract and how in turn, the psychological contract influences programme evaluation at the individual level. This research highlights that graduates enter 'fast track' development programmes with a shared set of preconceived expectations, partially shaped by their own sense of graduate identity but also reinforced through recruitment processes. This leads to the formation of a shared talent based 'graduate psychological contract' which underpins and frames early work experiences. Importantly we have highlighted how factors that pre-date the current employment relationship, and that are external to the organisation (public sector brand, influence from family and friends), shape expectations of the talent management programme. Organisations therefore need to consider the notion of a 'shared' psychological contract, "that emerges when members of a social group...hold common beliefs." (Rosseau, 1995 p 9.), particularly as the nature of many talent management programmes means that individuals are often recruited and managed to some extent at a group level (Laulié and Tekleab, 2016).

Second, we have highlighted the importance of managing and moderating the development of expectations for individuals on talent management programmes. Talent management recruitment and selection processes make explicit promises to groups of individuals about what they, as participants of a talent management programme, can expect and whilst for some 
their experiences may be congruent with these expectations, for others they are not. Prior research has shown that the pre-entry expectations of graduates tend to be unrealistically optimistic and often not matched by post-entry experiences (Mabey et al. 1996). We suggest that while public sector organisations may not be able to control all aspects of the 'graduate psychological contract' they can significantly influence graduate expectations through recruitment and selection processes. For example, they can provide more explicit information about the nature and structure of the programme and can ensure that graduates understand what they will not receive, as well as what will be offered. Thus organisations need to consider how they market talent management programmes as this is a key element in managing the psychological contract and ensuring the success of 'fast track' talent programmes. Realistic recruitment processes also have the potential to reduce the gap between expectations and experiences thus increasing the likelihood that graduates will perceive that their psychological contract has been fulfilled.

Third, we have shown that the success of public sector 'fast track' programmes relies on both the talent management strategy (for example how talent is identified and recruited) and talent management implementation (how talent is developed and deployed) (Capelli and Keller 2013; Gelens et al. 2014). As figure 1 highlights, these elements contribute to the individual talent management experience by shaping expectations and then determining how the experience is evaluated. Incongruent and inconsistent experiences that do no not match what has been promised - explicitly or implicitly, and individually or collectively - not only lead to dissatisfaction and disappointment but also mean that potential is not fully realised. We suggest that if graduates are to be developed in keeping with the goals and principles of talent management, then those managing the programmes need to focus on both the strategic and operational aspects of 'fast track' graduate development. We have highlighted the need for such programmes to have systematic processes and developmental opportunities that lead to congruent messages rather than unstructured processes that rely heavily on line managers for effective implementation. We argue that there needs to be a recognition of the multi-agentic nature of talent management and the ways in which multiple actors (HR department, senior managers and line managers) involved in the strategy development and implementation shape participant expectations and experiences. Guest and Conway (2002) observe that when seeking to 'manage' the psychological contract a major challenge for organisations is that the various actors may communicate different promises, or may fail to recognise the promises 
made by other participants to the contract. However, effective talent management programmes require coordination and clear communication across all levels in the organisation and at different stages of implementation.

We recognise the limitations of this study. First, the data in relation to expectations prior to joining the programme were based on retrospective reports by participants. Although this is acknowledged to be a valid method (Bujold, 2004), future research would benefit from accessing individuals at the start of the programme to capture prior expectations against which to compare post-experience evaluations. Second, participants had been on the programmes for different lengths of time and we were not able to explore the experience as it unfolded, nor examine the outcomes for the individual and the organisation in the longer term. In future studies, it would be useful to explore individual experiences longitudinally. This would allow further insights into the process of psychological contract formation beginning with the pre-joining stage and facilitate a deeper understanding of how participating in a talent management programme impacts on graduate career progress.

In summary, as public sector organisations grapple with the loss of their Baby Boomer workforce, graduate development programmes have the potential to help manage the transition to the next generation of leaders but our research highlights that those responsible for talent management need to move beyond strategic visions and branding to consider how such programmes are implemented as this is likely to determine the extent to which they fully retain and utilize this new talent. The themes that emerged across the two cases provide strong evidence that for many graduates 'fast track' talent management programmes are not meeting participant expectations due to a lack of congruence between different elements such as shared pre-programme expectations, organisational talent management practices and implementation processes. Given that graduate programmes are an important source of talent for the public sector, our paper draws upon the psychological contract to provide theoretical and practical insights into how graduate talent can be more effectively engaged and developed in ways that meet both individual and organisational needs. 


\section{REFERENCES}

Al Ariss, A., Cascio, W. \& Paauwe, J. (2014).Talent Management: Current theories and future research directions. Journal of World Business, 49(2): 173-179.

Alfes, K., Shantz, A. D., Truss, C. \& Soane, E.C. (2013a). The link between perceived human resource management practices, engagement and employee behaviour: a moderated mediation model. The International Journal of Human Resource Management, 24(2): 330-351.

Alfes, K., Truss, C., Soane, E.C. \& Gatenby, M. (2013b). The relationship between line manager behavior, perceived HRM practices, and individual performance. Human Resource Management, 52(6): 839-859.

Altman, Y. (1997). The high-potential fast flying achieve: themes from the English language literature 1976-1995. Career Development International, 2(7): 324-330.

Arnold, J. \& Mackenzie Davey, K. (1999). Graduate work experiences a predictors of organizational commitment: what experiences really matter? Applied Psychology: An International Review, 48: 211-238.

Ashton, C. \& Morton, L. (2005). Managing talent for competitive advantage: Taking a systemic approach to talent management. Strategic HR Review, 4(5): 28-31.

Bal, P. M., Kooij, D. \& De Jong, S. B. (2013). How do developmental and accommodative HRM enhance employee engagement and commitment? The role of psychological contract and SOC strategies. Journal of Management Studies, 50(4): 545-572.

Beechler, S. \& Woodward, I.C. (2009). The global "war for talent". Journal of International Management, 15(3): 273-285.

Bjorkman, I., Ehrnrooth, M., Makela, K., Smale, A. \& Sumelius, J. (2013). Talent or not? Employee reactions to talent identification. Human Resource Management, 52(2): 195-214.

Blau, P.M. (1964). Exchange and power in social life. New York, NY, Wiley.

Boudreau, J.W. \& Ramstad, P.M. (2005a). Talentship, talent segmentation and sustainabilty: A new HR decision science paradigm for a new strategy definition. Human Resource Management, 44(2): 129-136.

Boudreau, J.W. \& Ramstad, P.M. (2005b). Where's your pivotal talent? Harvard Business Review, 83(4): 23-24.

Bowen, D. \& Ostroff, C. (2004).Understanding HRM - firm performance linkages: the role of the 'strength' of the HR system. Academy of Management Review, 29(2): 203-221.

Bujold, C. (2004). Constructing career through narrative. Journal of Vocational Behavior, 64(3): 470-484.

Burke, R.J., Allisey, A.F. \& Noblet, A.J. (2013). The importance of human resource management in the public sector, future challenges and the relevance of the current collection. Human Resource Management in the Public Sector. Burke RJ, Noblet AJ and Cooper C. Cheltenham UK, Edward Elgar: 1-16.

Cappelli, P. (2008) Talent on demand: Managing talent in an age of uncertainty, Harvard Business School Press, Boston, Mass.

Cappelli, P. \& Keller, J.R. (2013) . Classifying work in the new economy . Academy of Management Review, 38(4): 575-596.

Cappelli, P. \& Keller, J. R. (2014). Talent management: Conceptual approaches and practical challenges. Annual Review of Organizational Psychology and. Organizational Behaviour, 1(1): 305-331.

CIPD. (2014). Talent Management. An overview. from http://www.cipd.co.uk/hrresources/factsheets/talent-management-overview.aspx. 
Collings, D.G. \& Mellahi, K. (2009). Strategic talent management: A review and research agenda. Human Resource Management Review, 19(4): 304-313.

Connor, H., Shaw, S., O'Donnell, H., Karallis, T., Sandelands, E., Cassin, J. \& O'Neill, D. (2008). Case study: developing graduate engineers at Kentz Engineers \& Constructors.Education+ Training, 50(5): 439-452.

Conway, N. \& Briner, R. (2005). Understanding the Psychological Contracts at Work: A critical evaluation of theory and research, Oxford University Press: Oxford

Coyle-Shapiro, J. \& Kessler, I. (2000). Consequences of the psychological contract for the employment relationship: A large scale survey. Journal of Management Studies, 37(7): 903-930.

Coyle-Shapiro, J. A. M. \& Parzefall, M. (2008). Psychological contracts. The SAGE handbook of organizational behavior: 17-34.

Crawshaw, J. R., \& Game, A. (2015). The role of line managers in employee career management: an attachment theory perspective. The International Journal of Human Resource Management, 26(9), 1182-1203.

Cullinane, N. \& Dundon, T. (2006). The psychological contract: A critical review. International Journal of Management Reviews, 8(2): 113-129.

Cuyper, N., \& Witte, H. (2006). The impact of job insecurity and contract type on attitudes, well-being and behavioural reports: a psychological contract perspective. Journal of Occupational and Organizational Psychology, 79(3): 395-409.

De Vos A., Buyens D. \& Schalk R. (2003) "Psychological contract development during organizational socialization: adaptation to reality and the role of reciprocity" Journal of Organizational Behavior, 24(5): 537-559.

De Vos, A. \& Dries, N. (2013). Applying a talent management lens to career management: The role of human capital composition and continuity. The International Journal of Human Resource Management, 24(9): 1816-1831.

De Vos A., De Stobbeleir K. \& Meganck A. (2009). The relationship between career-related antecedents and graduates' anticipatory psychological contracts. Journal of Business Psychology, 24(3): 289-298.

Denzin, N. K., \& Lincoln, Y. S. (2011). The SAGE handbook of qualitative research. Sage.

Devine, M. \& Powell, M. (2008). Talent Management in the Public Sector. The Ashridge Journal, Autumn: 1-6.

Dries N. (2013). The psychology of talent management: A review and research agenda. Human Resource Management Review, 23(4): 272-285.

Dries, N. \& Pepermans, R. (2007). "Real" high-potential careers: An empirical study into the perspectives of organisations and high potentials. Personnel Review, 37(1): 85-108.

Farndale, E., Scullion, H. \& Sparrow, P. (2010). The role of the corporate HR function in global talent management. Journal of World Business, 45(2): 161-168.

Festing, M., \& Schäfer, L. (2014). Generational challenges to talent management: A framework for talent retention based on the psychological-contract perspective. Journal of World Business ,49 (2): 262-271.

Gallardo-Gallardo, E., Dries, N. \& González-Cruz, T. F. (2013). What is the meaning of 'talent' in the world of work? Human Resource Management Review, 23(4): 290-300.

Garrow, V.\& Hirsh, W. (2008). Talent management: Issues of focus and fit. Public Personnel Management, 37(4): 389-402.

Gelens, J., Hofmans, J., Dries, N. \& Pepermans, R. (2014). Talent management and organisational justice: employee reactions to high potential identification. Human Resource Management Journal, 24(2): 159-173. 
Gilbert, C., De Winne, S. \& Sels, L. (2011). The influence of line managers and HR department on employees' affective commitment. The International Journal of Human Resource Management, 22(8): 1618-1637.

Guest, D. E. \& Conway, N. (2002). Communicating the psychological contract: an employer perspective. Human Resource Management Journal ,12(2): 22-38.

Harney, B. \& Jordan, C. (2008). Unlocking the black box: line managers and HRMperformance in a call centre context. International Journal of Productivity and Performance Management, 57(4): 275-296.

Hinchliffe, G.W. and Jolly, A. (2011). Graduate identity and employability. British Educational Research Journal, 37(4): 563-584.

Hoglund, M. (2012). Quid pro quo? Examining talent management through the lens of psychological contracts. Personnel Review, 41(2): 126-142.

Holmes, L. (2001). Reconsidering graduate employability: the 'graduate identity' approach. Quality in Higher Education, 7(2): 111-119.

Holmes, L. (2013). Competing perspectives on graduate employability: possession, position or process?. Studies in Higher Education, 38(4): 538-554.

Huang, J. \& Tansley, C. (2012) . Sneaking through the minefield of talent management: the notion of rhetorical obfuscation. International Journal of Human Resource Management, 23(17): 3673-3691.

Iles, P., Preece, D. \& Chuai, X. (2010). Talent management as a management fashion in HRD: towards a research agenda. Human Resource Development International, 13(2): 125-145.

Jenner, S. (2008). Graduate development, discursive resources and the employment relationship at BAE systems. Education and Training, 50(5): 423-438.

Kesler, G.C. (2002). Why the leadership bench never gets deeper: Ten insights about executive talent development. Human Resource Planning, 25: 32-44.

Khilji, S. E. \& Wang, X. (2006). 'Intended'and 'implemented'HRM: the missing linchpin in strategic human resource management research. The International Journal of Human Resource Management, 17(7): 1171-1189.

King, Z. (2003). New or traditional careers? A study of UK graduates' preferences. Human Resource Management Journal,13(1): 5-26.

King, N. (2004). Using templates in the thematic analysis of texts. Essential guide to qualitative methods in organizational research. Cassell C and Symon C. London, Sage Publications: 256-270.

Kuznia, K. (2004). The rhetoric and reality of fast track management development programs. Annual Conference Proceedings, Midwest Academy of Management.

Larsen, H.H. (1996). In search of management development in Europe: from self-fulfilling prophecies to organizational competence. International Journal of Strategic Human Resource Management, 77(3): 657-676.

Laulié, L., \& Tekleab, A. G. (2016). A Multi-Level Theory of Psychological Contract Fulfillment in Teams. Group \& Organization Management, 41(5): 658-698.

Lee, C., Liu J., Rousseau, D.M., Hui C. \& Chen Z. X. (2011). Inducements, contributions, and fulfillment in new employee psychological contracts. Human Resource Management, 50(2): 201-226.

Lewis, G.B. \& Frank, S.A. (2002). Who wants to work for the Government? Public Administration Review, 62(4): 395-404.

Mabey, C., Clark, T. \& Daniels, K. (1996). A six year longitudinal study of graduate expectations: the implications for company recruitment and selection strategies. International Journal of Selection and Assessment, 4(3): 139-150. 
McCracken, M., Currie, D. \& Harrison, J. (2016). Understanding graduate recruitment, development and retention for the enhancement of talent management: sharpening 'the edge' of graduate talent. International Journal of Human Resource Management, Vol. 27, No. 22, 2727-2752.

McDonnell, A., Lamare, R., Gunnigle, P. \& Lavelle, J. (2010). Developing tomorrow's leaders-Evidence of global talent management in multinational enterprises. Journal of World Business, 45(2): 150-160.

Miles, M.B. \& Huberman, A.M. (1994). Qualitative Data Analysis. Thousand Oaks, Sage.

Minbaeva, D. \& Collings D.G. (2013). Seven myths of global talent management. International Jounal of Human Resource Management. 24(9): 1762-1776.

Patton, M.Q. (1990). Qualitative Evaluation and Research Methods. Newbury Park, Sage.

Pilkington, C. (1999). The civil service in Britain today, Manchester University Press.

Pitcher, J. \& Purcell, K. (1998). Diverse expectations and access to opportunities: is there $a$ graduate labour market?. Higher Education Quarterly, 52(2): 179-203.

Poocharoen, O. \& Lee, C. (2013). Talent management in the public sector. Public Management Review, 15(8): 1185-1207.

Purcell, K. \& Hutchinson, S. (2007). Front-line managers as agents in the HRM-performacne causal chain. Human Resource Management Journal, 17(1): 3-20.

QSR (2011). NVivo (Application Software Package). Melbourne, Qualitative Software and Research.

Reis, H. T. \& Gable, S. L. (2000). Event-sampling and other methods for studying everyday experience. Handbook of Research Methods in Social and Personality Psychology. H. T. Reis and C. M. Judd. New York, N.Y., Cambridge University Press: 190-222.

Robinson, S.L., Kraatz, M.S. \& Rousseau, D.M. (1994) . Changing obligations and the psychological contract: A longitudinal study. Academy of Management Journal, 37 : 137-152.

Rousseau, D.M. (1990). New hire perceptions of their own and their employer's obligations: A study of psychological contracts. Journal of Organizational Behavior, 11: 389-400.

Rousseau, D. (1995). Psychological contracts in organizations: Understanding written and unwritten agreements. Sage Publications.

Rousseau, D. (2001) . Schema, promise and mutuality: The building blocks of the psychological contract. Journal of Occupational and Organizational Psychology, 74: $511-541$.

Sandberg, J. (2005). How do we justify knowledge produced within interpretive approaches?. Organizational Research Methods, 8(1), 41-68.

Scullion H. \& Collings D.G. (2011). Global Talent Management. London, Routledge.

Sekaran, U. (2000). Research Methods for Business. New York, Wiley.

Shipton, H., Sanders, K., Atkinson, C. \& Frenkel, S. (2016). Sense-giving in health care: the relationship between the HR roles of line managers and employee commitment. Human Resource Management Journal, 26(1): 29-45.

Sturges, J. \& Guest, D. (2001). Don't leave me this way! A qualitative study of influences on the organisational commitment and turnover intentions of graduates early in their career. British Journal of Guidance and Counselling, 29(4): 447-462.

Sturges, J., Guest, D., Conway, N. and Davey, K.M. (2002) .A longitudinal study of the relationship between career management and organizational commitment among graduates in the first ten years of work. Journal of Organizational Behavior, 23(6): 731-748.

Sutton, G. \& Griffin, M. A. (2004). Integrating expectations, experiences, and psychological contract violations: A longitudinal study of new professionals. Journal of Occupational and Organizational Psychology, 77(4): 493-514. 
Tansley, C. (2011) . What do we mean by the term "talent" in talent management?. Industrial and Commercial Training, 43(5): 266-274.

Tansley, C. \& Tietze, S. (2013) . Rites of passage through talent management progression stages: an identity work perspective. International Journal of Human Resource Management, 24(9): 1799-1815.

Tansley, C., Turner P., Foster C., Harris I., Sempik A., Stewart J. \& Williams H. (2007). Talent: Strategy, management and measurement - Research into practice. London, Chartered Institute of Personnel and Development.

Tarique, I. \& Schuler, R. S. (2010). Global talent management: Literature review, integrative framework, and suggestions for further research. Journal of World Business, 45(2): 122-133.

Taylor, J. (2005). Recruiting university graduates for the public sector: an Australian case study. International Jounal of Public Sector Management, 18(6): 514-533.

Thunnissen, M., Boselie, P. \& Fruytier, B. (2013). Talent management and the relevance of context: Towards a pluralist approach. Human Resource Management Review, 23(4): 326-336.

Tomprou, M. \& Nilolaou I. (2011). A model of psychological contract creation upon organizational entry. Career Develpment International, 16(4): 342-363.

White House Press Office (2010) Executive Order - Recruiting and Hiring Students and Recent Graduates, 27 December 2010. Available at http://www.whitehouse.gov/thepress-office/2010/12/27/executive-order-recruiting-and-hiring-students-and-recentgraduates . Accessed: 01/11/2011.

Viney, C., Adamson, S. \& Doherty, N. (1996) . Paradoxes of fast-track career management. Personnel Review, 26(3): 174-116.

Wright, B. E. (2001). Public Sector Work Motivation: A Review of the Current Literature and a Revised Conceptual Model. Journal of Public Administration Research and Theory, 11(4): 559-586.

Yarnall, J. (1998) . Line managers as career developers. Personnel Review, 27(5): 378-395.

Yarnall, J. (2011). Maximising the effectiveness of talent pools: a review of case study literature. Leadership \& Organization Development Journal, 32(5): 510-526.

Yin, R. K. (2013). Case study research: Design and methods, Sage publications.

Youndt, M.A., Subramaniam, M. \& Snell S.A. (2004) . Intellectual capital and the resource based view of the firm. Journal of Management Studies, 41(2): 335-361. 